\title{
A Detention Reservoir Reduced Combined Sewer Overflows and Bathing Water Contamination Due to Intense Rainfall
}

\author{
Marco Romei ${ }^{1}$, Matteo Lucertini ${ }^{1}$, Enrico Esposito Renzoni ${ }^{1}$, Elisa Baldrighi ${ }^{2, *}$, Federica Grilli ${ }^{2}$ (D), \\ Elena Manini ${ }^{2}$, Mauro Marini ${ }^{2,3}$ and Luca Iagnemma ${ }^{4, *}$ \\ 1 ASET SpA, Via Luigi Einaudi, 61032 Fano, Italy; m.romei@asetservizi.it (M.R.); \\ ma.lucertini@asetservizi.it (M.L.); e.espostorenzoni@asetservizi.it (E.E.R.) \\ 2 National Research Council, Institute of Marine Biological Resources and Biotechnologies, CNR IRBIM, \\ 60125 Ancona, Italy; federica.grilli@cnr.it (F.G.); elena.manini@cnr.it (E.M.); mauro.marini@cnr.it (M.M.) \\ 3 Fano Marine Center, The Inter-Institute Center for Research on Marine Biodiversity, \\ Resources and Biotechnologies, 61032 Fano, Italy \\ 4 Department of Infrastructures and Transport Abruzzo Region, 65127 Pescara, Italy \\ * Correspondence: elisa.baldrighi@irbim.cnr.it (E.B.); luca.iagnemma@regione.abruzzo.it (L.I.)
}

check for updates

Citation: Romei, M.; Lucertini, M.; Esposito Renzoni, E.; Baldrighi, E.; Grilli, F.; Manini, E.; Marini, M.; Iagnemma, L. A Detention Reservoir Reduced Combined Sewer Overflows and Bathing Water Contamination Due to Intense Rainfall. Water 2021, 13, 3425. https://doi.org/10.3390/ w13233425

Academic Editors: Sabina Susmel, Elisa Baldrighi, Maja Krzelj, Josipa Bilic, Viviana Scognamiglio and Mauro Celussi

Received: 19 October 2021

Accepted: 1 December 2021

Published: 3 December 2021

Publisher's Note: MDPI stays neutral with regard to jurisdictional claims in published maps and institutional affiliations.

Copyright: (c) 2021 by the authors. Licensee MDPI, Basel, Switzerland. This article is an open access article distributed under the terms and conditions of the Creative Commons Attribution (CC BY) license (https:// creativecommons.org/licenses/by/ $4.0 /)$.

\begin{abstract}
Combined sewer overflows (CSOs) close to water bodies are a cause of grave environmental concern. In the past few decades, major storm events have become increasingly common in some regions, and the meteorological scenarios predict a further increase in their frequency. Consequently, CSO control and treatment according to best practices, the adoption of innovative treatment solutions and careful sewer system management are urgently needed. A growing number of publications has been addressing the quality, quantity and types of available water management and treatment options. In this study, we describe the construction of an innovative detention reservoir along the Arzilla River (Fano, Italy) whose function is to store diluted CSO wastewater exceeding the capacity of a combined drain system. River water sampling and testing for microbial contamination downstream of the tank after a heavy rain event found a considerable reduction of fecal coliform concentrations, which would have compounded the impact of stormwater on the bathing site. These preliminary results suggest that the detention tank exerted beneficial environmental effects on bathing water by lowering the microbial load.
\end{abstract}

Keywords: combined sewer overflows; bathing water; fecal pollution; climate changes; Adriatic sea

\section{Introduction}

Climate change is affecting rainfall regimes all over the planet. Long-term series of observations provide unique and valuable datasets that allow for the reliable detection of the average annual cycle patterns as well as of significant changes due to global or local impacts [1,2]. In some regions of the world, extreme weather events, defined as events that are rare within their statistical reference distribution in a particular area [3,4], have increased in frequency or intensity. Violent summer rains have also been recorded at temperate latitudes, like the Adriatic area in Europe [5].

In northeastern Italy, extreme rainfall events increased in 1920-1998, despite a negative trend in the number of wet days. A recent study of the magnitude and frequency of annual rainfall maxima in Italy in 1928-2014 [6] found a clear rising trend in extreme rainfall magnitude and intensity in some areas at the regional scale.

Summer and autumn are typically characterized by intense precipitation. Extreme rain events induce flash floods and sewer overflows, putting human life at risk and affecting coastal ecosystems, also by increasing fecal bacteria loads in runoff water and ultimately seawater $[7,8]$. Fecal contamination is of major public and scientific interest, since bathing water quality affects both human health and the ecosystem [9], besides tourism and the economy. 
Bathing water hosts ubiquitous populations of water-living and free-living microorgan isms-both pathogenic and non-pathogenic - that derive from human activities [10]. Notably, poor microbial water quality at recreational beaches can cause a wide range of complaints including eye, ear, skin, gastrointestinal and respiratory conditions [11]. Under Italian law, bathing water management and monitoring is regulated by Government Decree no. 116/2008 and the EU Bathing Water Directive (BWD; 2006/7/EC). The BWD sets restrictive water quality standards based on the concentrations of fecal indicator bacteria (i.e., E. coli and enterococci). The Government Decree no. 116/2008 regulates the monitoring, classification and management of bathing water. Bathing water quality is assessed at scheduled intervals. The weakness of this approach is that even after massive precipitations events, the results of bacterial analyses are available only after $48 \mathrm{~h}$, and in the interval, bathing is still allowed.

Researchers and policymakers have been trying to address the problems posed by the proximity of several bathing waters and recreational beaches to urban areas and by the high environmental pressure to which they are subject [12].

According to the Council Directive 91/271/EEC [13], concerning urban wastewater treatment, collecting systems in each municipality must consider wastewater treatment requirements while the design, construction and maintenance of collecting systems are undertaken in accordance with the best technical knowledge, while not entailing excessive costs. However, urban sewerage systems are seldom fully efficient and at times even modest rainfall can exceed their capacity, resulting in overflows [14]. In the past few years, several studies have tried to improve the management of diluted wastewater exceeding sewer system capacity with a view to protecting the natural environment and to limit flooding in case of intense rainfall. Some of these solutions involve the detention of diluted wastewater, which is then treated in the existing wastewater treatment plants. Other approaches provide for both storage and immediate treatment [15]. The former projects involve the construction of a detention reservoir to collect the first flush rainwater. After the rain event, a pumping station discharges the wastewater into the existing network downstream of the tank [16]. The approaches providing for storage and immediate treatment rely on the availability of ample non-built surfaces, which enable the natural treatment of polluted water by methods such as treatment wetlands (e.g., free water surface, horizontal or vertical flow systems and hybrid systems), the construction of an equalization basin or mechanical treatment [17].

Storm water detention tanks are widely used for mitigating impacts of combined sewer overflows into receiving water bodies. Several examples of their effectiveness have been reported worldwide and have been applied in different scenarios, i.e., hydrological conditions, morphology of the area and different types of rainy events [18-21]. In all cited cases, which represent only some examples, an improvement in water quality was achieved. However, in the study of [22], the importance of local conditions in tank design and construction was stressed, and they concluded that it is almost impossible to standardize these methods. In some cases, the construction of detention reservoirs was coupled with the development of hydrological models to improve the understanding of hydrological dynamics [21] or with a dedicated integrated information and alert system [20] for an active management of water quality.

An innovative integrated approach to reduce bathing water contamination to improve the environmental quality of marine and coastal waters has recently been described $[8,23]$. It comprises a water quality sampling system upstream and downstream of the detention reservoir described herein, a predictive numerical model [23] of the temporal distribution in bathing water of any pollutants released into the river and a bathing water quality alert system for the general public, developed based on monitoring activities and the application of numerical modelling [8].

In this study, we report the effects of the first detention reservoir built in Marches (central Italy) to store diluted wastewater exceeding the capacity of the local combined drain system coming from a combined sewer overflow (CSO). 


\section{Materials and Methods}

\subsection{Study Area}

The study area, covering 7 hectares, lies near the Arzilla River and belongs to the Municipality of Fano, a seaside town in Marches (Figure 1). The area is strongly urbanized and a popular summer resort.

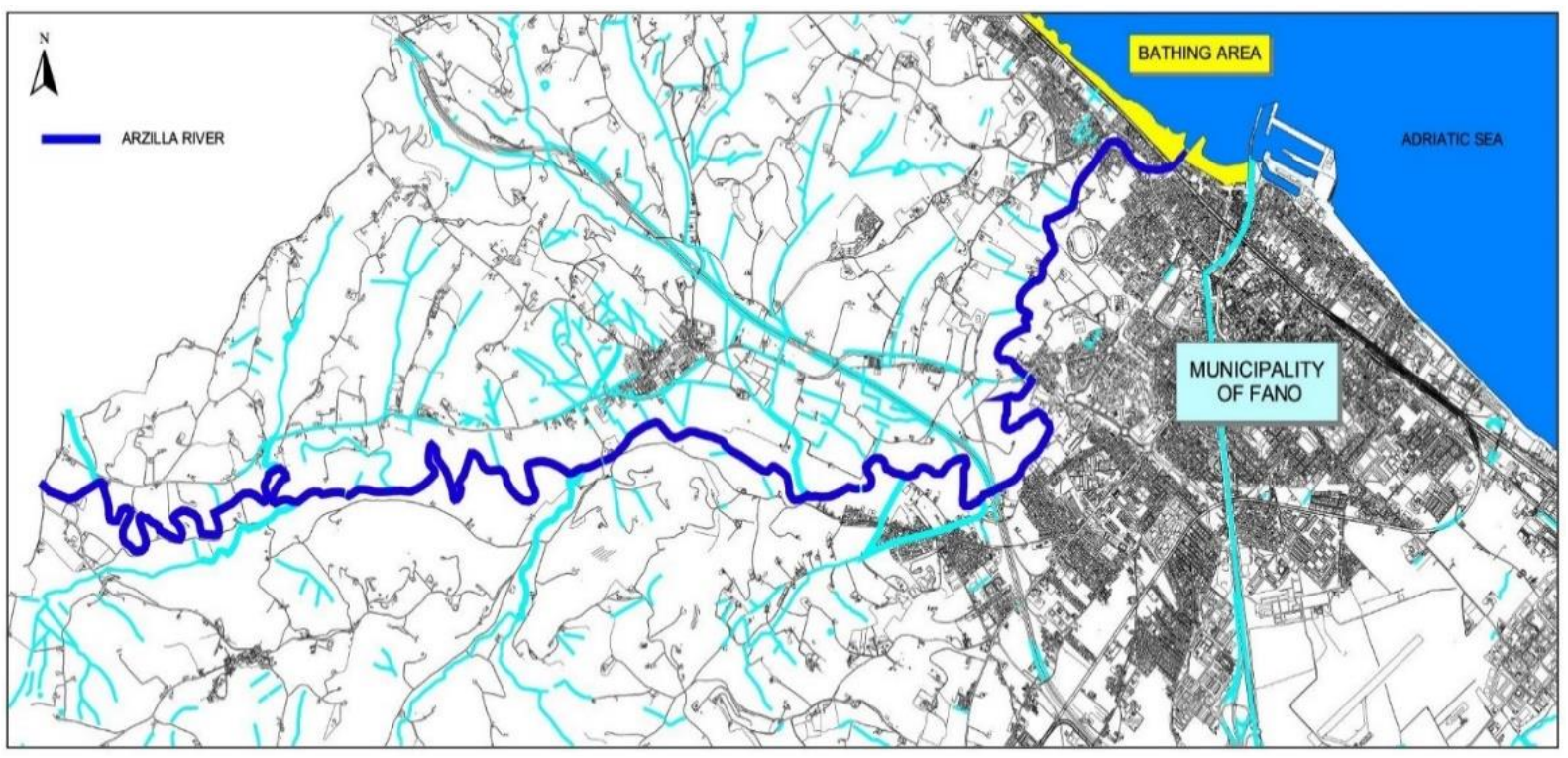

Figure 1. Study area with the course of the Arzilla River (blue) and the recreational beach (yellow).

As shown in Figure 2, there are two sewer catchments, one in via del Moletto (basin A; 3.40 hectares) and the other in via $1^{\circ}$ Maggio (basin $\mathrm{B} ; 3.80$ hectares), whose drainage systems are not connected to one another.

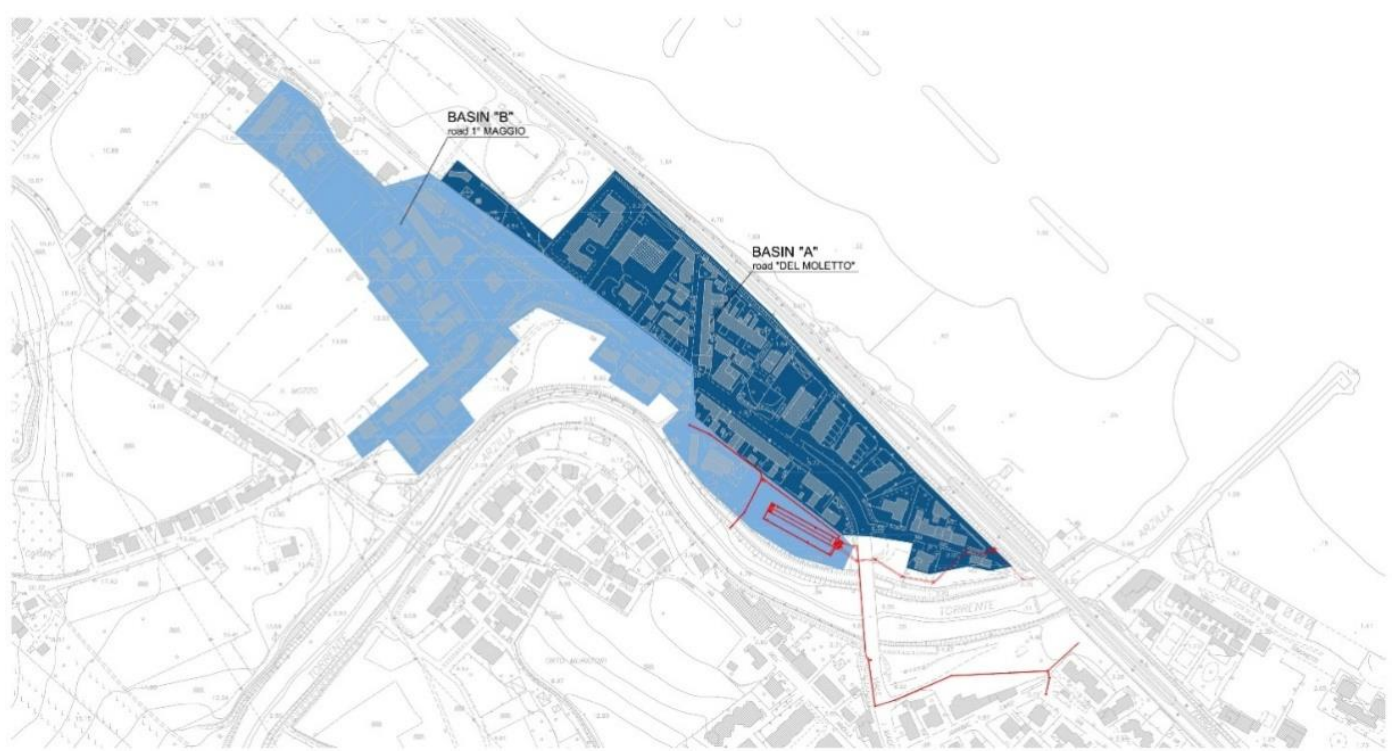

Figure 2. The two sewer catchments.

\subsection{Existing System and Project Description}

Before the intervention, the site was served by a combined sewer pipe. The system discharged the diluted wastewater into a $\mathrm{CSO}$, which, in the case of intense rainfall, divided the upstream flow in two, so that one flow was directed to a pumping station on the other 
side of the river and the other was discharged into the Arzilla River (Figure 3); this resulted in pollution of the river water and consequently the bathing water near the river mouth.

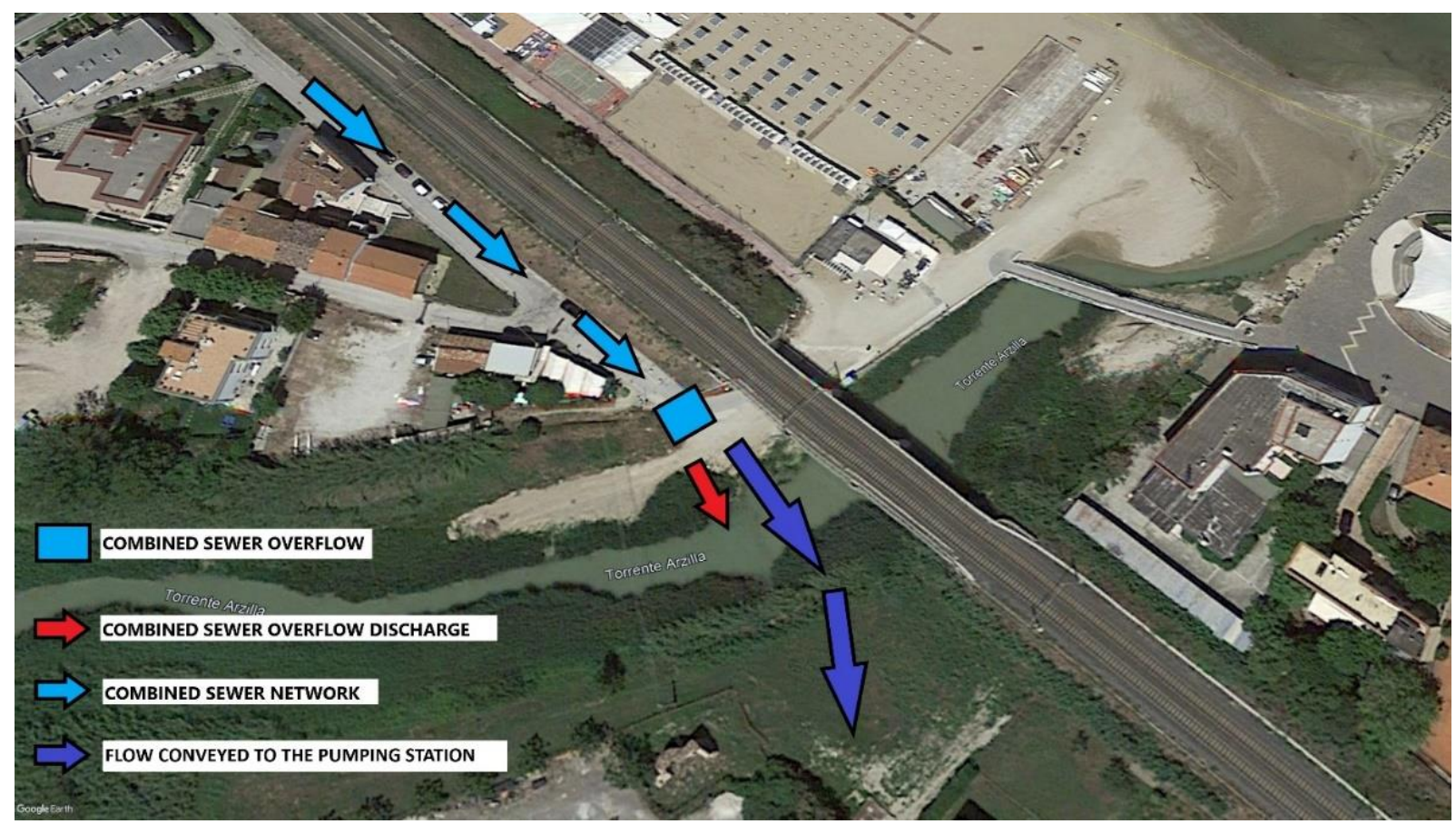

Figure 3. State of the site before the intervention.

The intervention described herein is part of a wider project and involved the construction, in basin A, of a new CSO that would discharge excess wastewater into a new underground detention reservoir (capacity, $1600 \mathrm{~m}^{3}$ ) through a gravity pipe of $500 \mathrm{~mm}$ in diameter. Another CSO and an additional sewer network will be realized to also convey the water from basin B into the reservoir. The new underground detention tank is made of special reinforced concrete lined with a chemical-resistant lining and a waterproof layer. It measures $60.20 \mathrm{~m} \times 14.05 \mathrm{~m}$ and its height ranges from $3.00 \mathrm{~m}$ to $2.42 \mathrm{~m}$. An emptying pump system delivers the water to the new pumping station, which then discharges the diluted wastewater into the existing sewer system (300 m away) for treatment in the wastewater treatment plant.

Remote-controlled sludge gates, installed in both CSOs, prevent excess filling of the tank through the activation of an emergency discharge mechanism.

\subsection{Feasibility Study and Design Criteria}

The project design began with the calculation of the wastewater flow rate upstream of the new reservoir.

The flow rate was estimated based on average tap water consumption over a period of $24 \mathrm{~h}$, corrected with a flow coefficient and with daily and hourly peak coefficients. The calculation yielded a flow rate of $3.20 \mathrm{~L} \mathrm{~s}^{-1}$ in basin A and $3.40 \mathrm{~L} \mathrm{~s}^{-1}$ in basin B.

The stormwater flow rate was calculated by means of a hydrological analysis of each basin using a regional rain model [19]. These statistical models are applied to extend datasets that are too limited or inadequate in terms of number or distribution to provide reliable results with common statistical models. Such regional models, called VAPI [24], are based on the hypothesis that there are compact and consistent areas sharing key hydrological characteristics. When a VAPI can be applied, the rainfall height and the relevant flow rate are calculated with a probabilistic approach [25], where each rain height value is associated with a probability of overshooting. 
The hydrological analysis provided flow rate values with a return period of 10 years equal to $250 \mathrm{~L} \mathrm{~s}^{-1}$ for basin A and $270 \mathrm{~L} \mathrm{~s}^{-1}$ for basin B.

A hydraulic analysis was also performed to estimate the capacity of the combined sewer network upstream of the new tank based on the diameters, slopes and state of conservation of the existing pipes. The calculations yielded a network capacity of $170 \mathrm{~L} \mathrm{~s}^{-1}$ and $120 \mathrm{~L} \mathrm{~s}^{-1}$ for basin $\mathrm{A}$ and basin B, respectively.

We used these values to calculate the diameter of the pipes that would have to be laid to connect the network to the new tank. Finally, we checked the capacity of the new pipes to accept the flow rate determined from the hydrological analysis based on a filling degree greater than $70 \%$. We calculated the tank storage volume by comparing the curve of the wastewater inflow (volume from the sewer network) to the wastewater outflow curve (capacity of the emptying pumps) (Figure 4). Given these conditions, and considering a constant rain intensity curve, the inflow volume as a function of time was found to be equal to the change in rainfall height over time multiplied by the drained surface. Since the outflow is a simple system of emptying pumps, it is represented as a constant function.

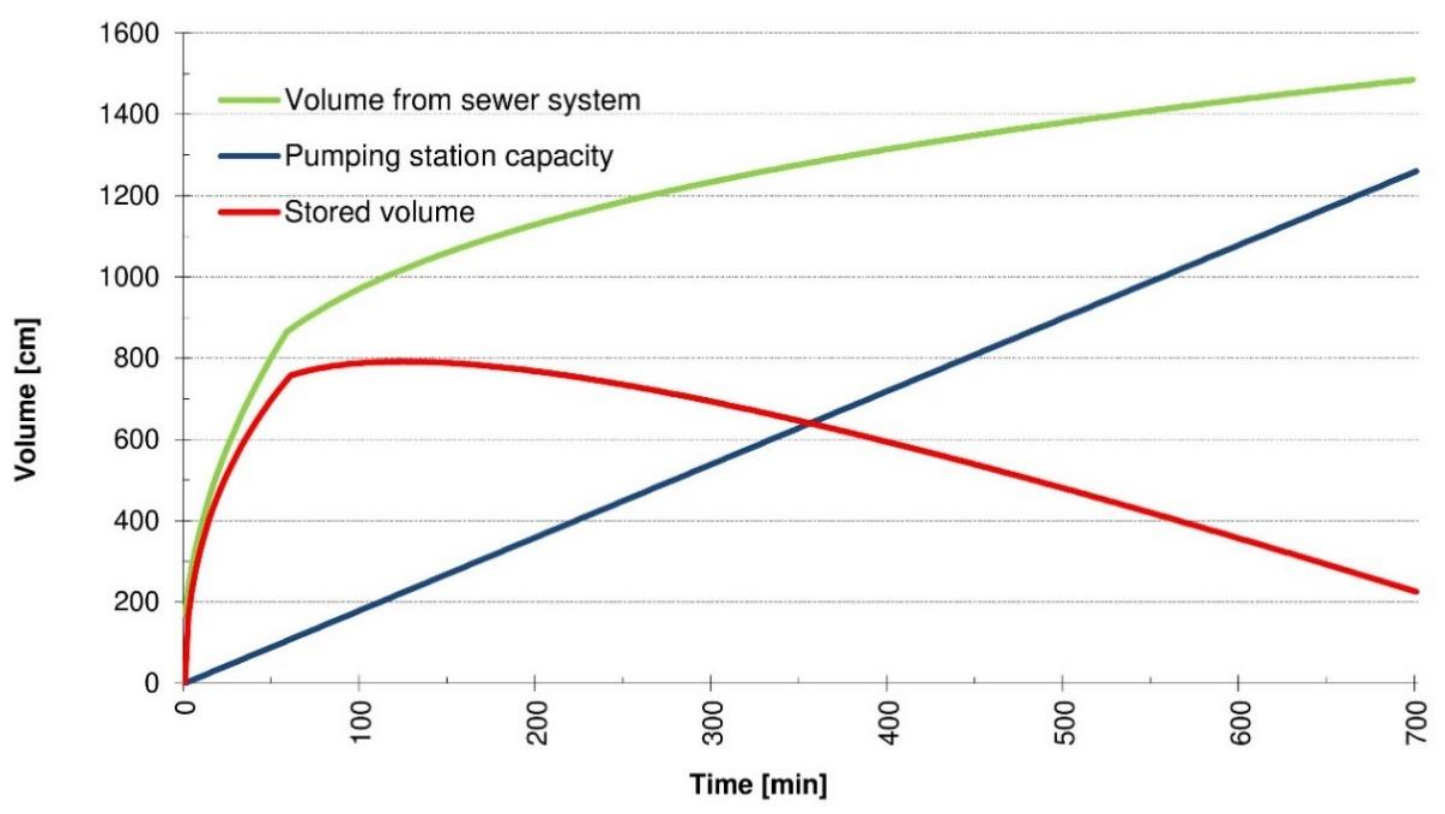

Figure 4. Graph showing the analysis of the detention tank volume with a return period of 10 years.

By this approach, the detention volume to be stored in the tank with a return period of 10 years and 50 years is about $800 \mathrm{~m}^{3}$ and $1300 \mathrm{~m}^{3}$, respectively.

The project also envisages two lifting stations, one to empty the storage tank and the other to pump the water to the existing network through a new pressure pipe.

The hydraulic sizing of the pumping stations considered the capacity of the existing sewer system that is to receive the wastewater. Therefore, the flow rate from the emptying pumps was set to ensure a suitable emptying time (ca. $24 \mathrm{~h}$ ) and consistency with the capacity of the existing sewer system.

The number of pumps operating in the two stations is managed remotely in relation to the water level reached in the storage tanks and the pumping station.

\subsection{Microbiological Analyses}

Water samples (three replicates) for the microbiological analysis of fecal contamination with Escherichia coli and intestinal enterococci were manually collected in sterile bottles (final volume $1000 \mathrm{~mL}$ ) from the detention tank and the Arzilla River, both upstream and at the river mouth. The bottles were immediately transported to the laboratory at in situ temperature in the dark and processed within a few hours of collection. E. coli and intestinal enterococci were analyzed using culture-based methods as described previously [8]. 


\section{Results and Discussion}

The detention tank is a key component of a wider pilot project envisaging the construction of an integrated system for the continuous monitoring of water (and seawater) quality in Fano.

This is the framework in which the detention reservoir will function. Its objective, in case of precipitation exceeding the return period, is to store all or part of the wastewater overflow, which is characterized by a high bacterial load. The efficiency of the new tank is being monitored via two continuous water sampling stations placed along the river immediately upstream and downstream of the two CSOs.

The block diagram in Figure 5 describes the as-built configuration of the plant. The wastewater from the two basins is delivered through three inlet pipes: two combined pipes with a nominal pipe size (NPS) of $500 \mathrm{~mm}$, with one from each basin, discharge the wastewater into the reservoir; the wastewater is subsequently pumped to the nearby left station. The third pipe with a NPS of $200 \mathrm{~mm}$ conveys the wastewater directly to the pumping station.

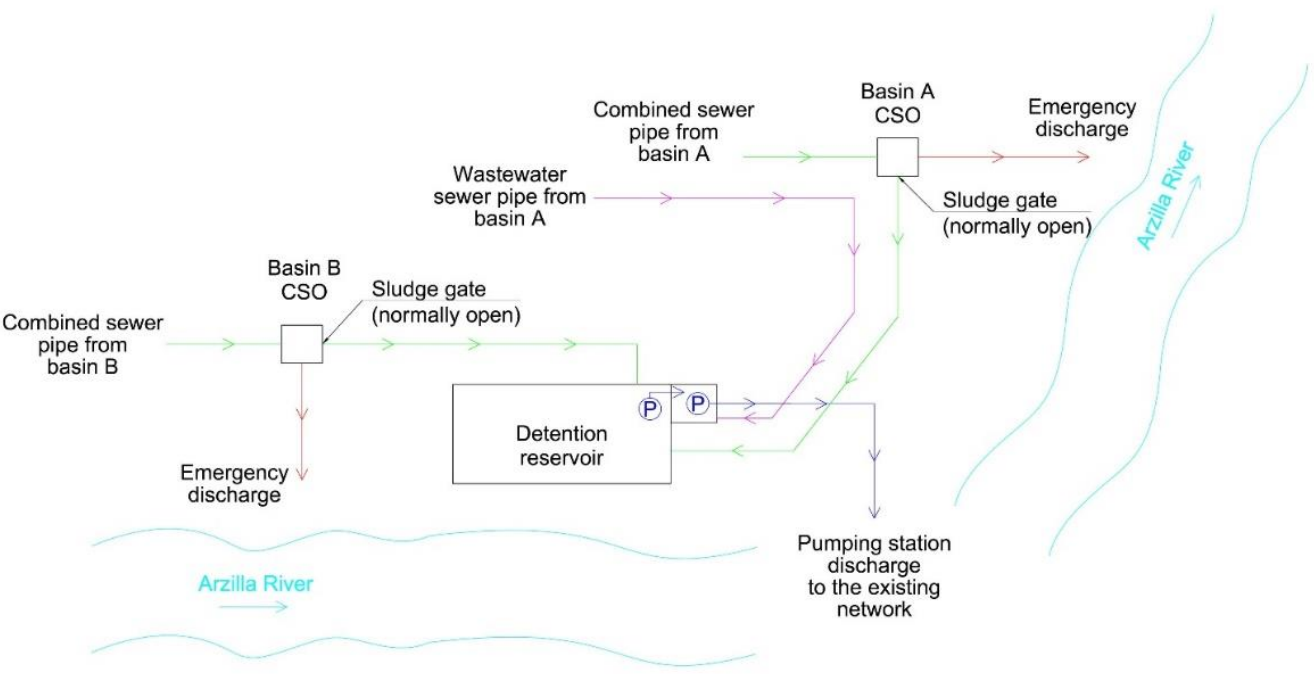

Figure 5. Operation scheme of the detention reservoir.

The pumping station feeds a pressure pipe that channels the wastewater to the existing sewer network.

Two protection systems (one per basin) ensure that the stored water does not exceed the maximum storage capacity based on the water level measured in the tank. If the water level exceeds the threshold, an automatic command opens the two CSOs and activates the emergency discharge.

\subsection{Tank System and Operation}

Since its commissioning and startup in June 2021, the detention reservoir has stored diluted wastewater on the occasion of a rain event, preventing wastewater discharge and the contamination of the river surface water. The rain height, rain intensity and event duration recorded by the rain gauge are reported in Table 1 together with the maximum volume of wastewater temporarily stored in the tank.

The stored volumes were not exactly proportional to the amount of precipitation, because the activation of the emptying pumps, which also work during the rain event, is regulated by a mechanism that considers the water level in the tank as well as the reads in the adjacent pumping station. Therefore, in case of a high water level in the pumping station, the emptying pumps are in stand-by and the stored volume can only increase. 
Table 1. Rainfall and wastewater storage in the tank in summer 2021.

\begin{tabular}{|c|c|c|c|c|}
\hline Date & Rain Height & $\begin{array}{c}\text { Rain Intensity, } \\
\text { Max }\end{array}$ & $\begin{array}{c}\text { Event } \\
\text { Duration }\end{array}$ & $\begin{array}{c}\text { Volume Stored } \\
\text { in Tank }\end{array}$ \\
\hline & $(\mathrm{mm})$ & $\left(\mathrm{mm} \mathrm{h}^{-1}\right)$ & (h-mm) & $\left(\mathrm{m}^{3}\right)$ \\
\hline 13 July 2021 & 17 & 176 & $1 \mathrm{~h} 0 \mathrm{~min}$ & 556 \\
\hline 16 July 2021 & 13 & 16 & $5 \mathrm{~h} 00 \mathrm{~min}$ & 513 \\
\hline 23 August 2021 & 30 & 260 & $0 \mathrm{~h} 40 \mathrm{~min}$ & 740 \\
\hline 25 August 2021 & 16 & 40 & $3 \mathrm{~h} 20 \mathrm{~min}$ & 438 \\
\hline 28 August 2021 & 15 & 20 & $2 \mathrm{~h} 00 \mathrm{~min}$ & 607 \\
\hline 26 September 2021 & 30 & 340 & $15 \mathrm{~min}$ & 807 \\
\hline
\end{tabular}

The first significant result was the magnitude of the wastewater level stored in the tank on the occasion of the rain events compared with the very low flow rate measured in the final stretch of the river in summer.

In addition, we observed that the filling degree of the detention reservoir recorded during the rain events was in line with the values calculated in the design stage.

\subsection{Microbial Load Control after the Tank}

Bathing water pollution by the CSOs of combined sewer systems on the occasion of intense precipitation is a cause for concern both from the standpoint of environmental health and in terms of beach usability and seawater safety [7], which is an issue that is especially important in areas, such as Fano, that receive major tourist flows.

The specific function of the tank is to retain the first rainwater during a rain event that involves the mixing of runoff water and the wastewater running through the sewerage system. The two water masses are usually characterized by a very high load of microbiological pollutants derived from the drainage runoff at the beginning of the rain event.

To assess the environmental effect of the reservoir, i.e., the reduction of microbial pollution of bathing water, and to quantify its impact, we collected water samples both in the tank and at two sites (upstream and mouth) along the Arzilla River after a rain event (26 September 2021) with the sludge gates open.

The concentrations of $E$. coli and intestinal enterococci measured in the tank were one order of magnitude higher than those measured at the two sites along the river (Figure 6). However, despite the large amount of fecal coliforms collected in the tank water, which would have compounded the impact of the storm on the bathing site, the concentrations at both river sampling sites located upstream and downstream of the new detention reservoir were very similar and still exceeded the limit set by Directive 2006/7/EC.

For this reason, we should always consider the possibility of the presence of other microbial contamination sources (i.e., overflows) located upstream of the river's hydrographic basin that did not find their way to the tank. With our preliminary data, it is not possible to validate this hypothesis, which was raised mostly from our knowledge of the area under study and human activities on the territory, but further analysis will be performed to explore other wastewater inputs.

However, we can say that constructing a storage tank capable of receiving the overflow of the sewer network in case of intense precipitation and a pumping station for subsequent wastewater delivery to the existing treatment plan proved to be effective. Indeed, during all recorded rainfall events after the tank activation (see Table 1), we were able to verify the correctness of the design assumptions, simulations and sizing and the ability of the new plant to meet expectations in every condition in which it was tested. Our preliminary results presented in this work open up the prospect of a more active urban water management that does not simply rely on monitoring activities, as also envisaged in the Bathing Water Directive (BWD 76/160/EEC). The BWD promotes the management of the water cycle as a whole and enforces responses in the case of non-compliance with directive standards. These 
responses may be infrastructural, like the building of water detention tanks, or contingent, like beach closures or the installation of warning signs for bathers. The detention reservoir can constitute an 'active' and ad hoc (i.e., the tank was built considering the characteristics of the area) response to face the problems derived from urban wastewater. Over a longer time scale, the presence of a detention reservoir will improve the quality of bathing water and also have benefits for all the recreational actives linked to the beaches and sea.

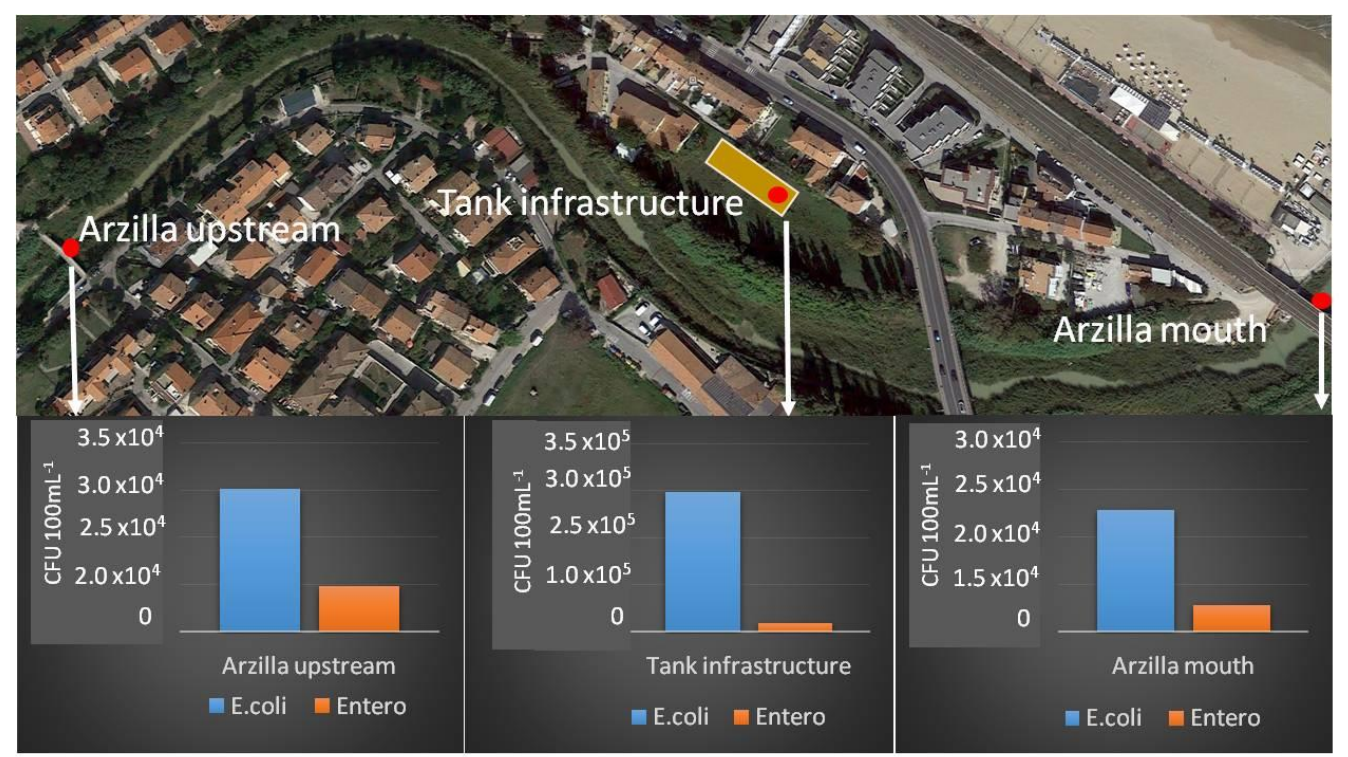

Figure 6. Escherichia coli (E. coli) and intestinal enterococci (Entero) measured the three sampling sites (Arzilla River, upstream; tank; and Arzilla River, mouth) after an intense rainy event (27 mm $\left.30 \mathrm{~min}^{-1}\right)$.

Author Contributions: Conceptualization, E.E.R. and M.M.; methodology, M.R., E.E.R., E.M. and M.L.; validation, M.R., M.L. and E.E.R.; formal analysis, E.E.R.; investigation, E.M. and E.B.; data curation, E.M. and M.M.; writing-original draft preparation, E.E.R., M.M., F.G., E.M. and E.B.; writing-review and editing, E.E.R., M.M., F.G., L.I. and E.B.; visualization, E.E.R., E.M. and E.B.; supervision, M.R., M.M. and L.I.; project administration, M.M.; funding acquisition, L.I. All authors have read and agreed to the published version of the manuscript.

Funding: This research was funded by WATERCARE project (Water management solutions for reducing microbial environment impact in coastal areas, project ID 10044130, https: / / www.italycroatia.eu/web/watercare, accessed on 17 October 2021) funded by the European Union under the Interreg Italy-Croatia CBC Program.

Institutional Review Board Statement: Not applicable.

Informed Consent Statement: Not applicable.

Data Availability Statement: Authors have the raw data readily available for presentation to the referees and the editors of the journal, if requested. Authors ensure appropriate measures are taken so that raw data is retained in full for a reasonable time after publication.

Acknowledgments: This work was supported by the WATERCARE project (Water management solutions for reducing microbial environment impact in coastal areas, project ID 10044130, https: //www.italy-croatia.eu/web/watercare, accessed on 17 October 2021) funded by the European Union under the Interreg Italy-Croatia CBC Program The authors are grateful to the Marches Region Civil Protection for providing the pluvio-hydrometric data from Santa Maria dell'Arzilla station and Elia Rosetti for his contribution in the dissemination phase of the project.

Conflicts of Interest: The authors declare no conflict of interest. 


\section{References}

1. Marini, M.; Fornasiero, P.; Artegiani, A. Variations of hydrochemical features in the coastal waters of Monte Conero: 1982-1990. Mar. Ecol. 2002, 23, 258-271. [CrossRef]

2. Morabito, G.; Mazzocchi, M.G.; Salmaso, N.; Zingone, A.; Bergami, C.; Flaim, G.; Accoroni, S.; Basset, A.; Bastianini, M.; Belmonte, G.; et al. Plankton dynamics across the freshwater, transitional and marine research sites of the LTER-Italy Network. Patterns, fluctuations, drivers. Sci. Total Environ. 2018, 627, 373-387. [CrossRef] [PubMed]

3. Pall, P.; Aina, T.; Stone, D.A.; Stott, P.A.; Nozawa, T.; Hilberts, A.G.J.; Lohmann, D.; Allen, M.R. Anthropogenic greenhouse gas contribution to flood risk in England and Wales in autumn 2000. Nature 2011, 470, 382-385. [CrossRef] [PubMed]

4. Trenberth, K.; Meehl, J.; Masters, J.; Somerville, R. Current Extreme Weather and Climate Change; Climate Comunication Report; 2011. Available online: https://www.climatecommunication.org/wp-content/uploads/2011/09/Extreme-Weather-and-ClimateChange.pdf (accessed on 30 November 2021).

5. Grilli, F.; Accoroni, S.; Acri, F.; Aubry, F.B.; Bergami, C.; Cabrini, M.; Campanelli, A.; Giani, M.; Guicciardi, S.; Marini, M.; et al. Seasonal and Interannual Trends of Oceanographic Parameters over 40 Years in the Northern Adriatic Sea in Relation to Nutrient Loadings Using the EMODnet Chemistry Data Portal. Water 2020, 12, 2280. [CrossRef]

6. Libertino, A.; Ganora, D.; Claps, P. Evidence for Increasing Rainfall Extremes Remains Elusive at Large Spatial Scales: The Case of Italy. Geophys. Res. Lett. 2019, 46, 7437-7446. [CrossRef]

7. Al Aukidy, M.; Verlicchi, P. Contributions of combined sewer overflows and treated effluents to the bacterial load released into a coastal area. Sci. Total Environ. 2017, 607-608, 483-496. [CrossRef] [PubMed]

8. Penna, P.; Baldrighi, E.; Betti, M.; Bolognini, L.; Campanelli, A.; Capellacci, S.; Casabianca, S.; Ferrarin, C.; Giuliani, G.; Grilli, F.; et al. Water quality integrated system: A strategic approach to improve bathing water management. J. Environ. Manag. 2021, 295, 113099. [CrossRef] [PubMed]

9. Amorim, E.; Ramos, S.; Bordalo, A.A. Relevance of temporal and spatial variability for monitoring the microbiological water quality in an urban bathing area. Ocean Coast. Manag. 2014, 91, 41-49. [CrossRef]

10. WHO Coastal and Fresh Waters. Guidelines for Safe Recreational Water Environments; World Health Organization: Geneva, Switzerland, 2003; Volume 1, pp. 1-219, ISBN 9241545801.

11. Wade, T.J.; Pai, N.; Eisenberg, J.N.S.; Colford, J.M. Do US Environmental Protection Agency water quality guidelines for recreational waters prevent gastrointestinal illness? A systematic review and meta-analysis. Environ. Health Perspect. 2003, 111, 1102-1109. [CrossRef] [PubMed]

12. Andersen, S.T.; Erichsen, A.C.; Mark, O.; Albrechtsen, H.J. Effects of a 20 year rain event: A quantitative microbial risk assessment of a case of contaminated bathing water in Copenhagen, Denmark. J. Water Health 2013, 11, 636-646. [CrossRef] [PubMed]

13. Council Directive no. 91/271/EEC. In Official Journal of the European Communities; European Union: Maastricht, The Netherlands, 1991; pp. 40-52.

14. Palazón, A.; López, I.; Aragonés, L.; Villacampa, Y.; Navarro-González, F.J. Modelling of Escherichia coli concentrations in bathing water at microtidal coasts. Sci. Total Environ. 2017, 593-594, 173-181. [CrossRef] [PubMed]

15. Regione Lombardia. Regione Lombardia-Bollettino Ufficiale Linea Guida Per la Progettazione e Realizzazione di Sistemi di Trattamento Delle Acque Reflue Provenienti da Scarichi di Sfioratori di Reti Fognarie. 2020. Available online: https: / / www.regione.lombardia.it (accessed on 30 November 2021).

16. Bornatici, L.; Ciaponi, C.; Papiri, S. Control Of Urban Runoff Stormwater Discharge To Receiving Waters Using Off-Line Storage. In Enhancing Urban Environment by Environmental Upgrading and Restoration; Marsalek, J., Sztruhar, D., GiulianelliBen, M., Urbonas, B., Eds.; Kluwer Academic: Dordrecht, The Netherlands, 2004; pp. 33-44.

17. Fonder, N.; Headley, T. Systematic Classification, Nomenclature and Reporting for Constructed Treatment Wetlands. In Water and Nutrient Management in Natural and Constructed Wetlands; Vymazal, J., Ed.; Springer: Berlin/Heidelberg, Germany, 2010; pp. 191-213, ISBN 9789048195848.

18. Liscum, F.; Goss, R.L.; Paul, E.M. Effects on Water Quality Due to Flood-Water Detention by Barker and Addicks Reservoirs; WaterResources Investigations Report 86-4356; U.S. Geological Survey: Austin, TX, USA, 1987.

19. Myers, B.; Sagi, I.; Van Leeuwen, J.; Beecham, S. Water Quality Improvement by Base Course Aggregate in a Permeable Pavement with Underlying Reservoir Structure. In Rainwater and Urban Design 2007; Australia: Barton, Australia, 2007; pp. 838-844, ISBN 1877040614.

20. Gutiérrez, E.; Malgrat, P.; Suñer, D.; Otheguy, P. Real Time Management of Bathing Water Quality in Barcelona. In Proceedings of the 7th International Conference on Sustainable Techniques and Strategies for Urban Water Management (NOVATECH 2007), Lyon, France, 16 July 2010; pp. 1-10.

21. Souza, F.P.; Costa, M.E.L.; Koide, S. Hydrological modelling and evaluation of detention ponds to improve urban drainage system and water quality. Water 2019, 11, 1547. [CrossRef]

22. Andrés-Doménech, I.; Segura, J.B.M. Multivariate rainfall distributions for stormwater detention tank sizing using probabilistic and single-event approaches. A comparison between northern and eastern Spain. In Proceedings of the 11th International Conference on Urban Drainage, Edinburgh, UK, 23 September 2008; pp. 1-10.

23. Ferrarin, C.; Penna, P.; Penna, A.; Spada, V.; Ricci, F.; Bilić, J.; Krzelj, M.; Ordulj, M.; Šikoronja, M.; Đuračić, I.; et al. Modelling the quality of bathing waters in the Adriatic sea. Water 2021, 13, 1525. [CrossRef] 
24. Ferrari, E.; Versace, P. La Valutazione delle Piene in Italia; Ferrari, E., Versace, P., Eds.; Consiglio Nazionale delle Ricerche: Roma, Italy, 1990.

25. Rossi, F.; Fiorentino, M.; Versace, P. Two-Component Extreme Value Distribution for Flood Frequency Analysis. Water Resour. Res. 1984, 20, 847-856. [CrossRef] 